\section{Hydrogenation of Coal in Australia}

INTEREST is rapidly growing in Australia in the possibilities of producing liquid fuel by hydrogenation of coal. The compelling factors are the difficulties placed by foreign oil producing countries in the way of payment by Australia in primary products, considerations of defence and the problem of unemployment in the coal mining areas. The Prime Minister has recently appointed a committee representative of the States, the Department of Defence, Synthetic Coal Oil Products Pty. Ltd., and the Council for Scientific and Industrial Research to report upon the present situation. An immediate question is whether black or brown coal should be taken as raw material and, after that, the terms of reference to the Committee include suitable location for a plant using 1,000 tons of coal per day ; costs of production ; amount of protection or subsidy or both necessary to maintain operations; and resulting employment, direct and indirect. Presumably Australia will be well advised to await the results of the large-scale operations of Imperial Chemical Industries Ltd., under weigh at Billingham; but the indications are that success in Britain will be followed rapidly by developments on one of the coal fields of the Commonwealth.

\section{Utilisation of Coal}

IN the Watt Anniversary Lecture for 1934 of the Greenock Philosophical Society, Prof. W. A. Bone emphasised the continued importance of the coal trade as the mainstay of our national economy. As an unrepentant Free Trader, he pleaded for freer international exchange and held the revival of the coal export trade to be vital to our recovery and to brook no delay. Modern tendencies to economic nationalism, especially in agriculture, were brushed aside. Prof. Bone skilfully outlined modern technical problems. $\mathrm{He}$ is not unduly afraid of oil, and gives only a limited approval of hydrogenation for liquid fuel, justifiable probably on strategic grounds only. The use of pulverised coal-freed from ash-appeals to him as a problem to be studied with all the resources at command and he believes that it would be solved if a James Watt or Charles Parsons were to take it in hand. In conjunction with this it is interesting to read an address on "The Utilisation of Coal" given by W. R. Gordon, director of the Coal Utilisation Council, before the Royal Society of Arts (J.Roy. Soc. Arts, June 8, 1934). Mr. Gordon outlined the function of the Council set up by the organisation of producers and distributors of coal. The consumer is not represented. Even such large consumers as the public utilities appear to be regarded as competitors, for the Council appears to have a bias for the use of raw coal. In the subsequent discussion, the neglect of the consumers' requirements received adverse comment.

\section{Modern Refrigerated Sea Transport}

IN the July number of the monthly journal Food, under the above title is a description of the Commonwealth and Dominion liner Port Chalmers, the first vessel specially built with gas-tight refrigerated compartments for the transport from New Zealand of chilled beef stored in an atmosphere containing carbon dioxide. The minimum temperature for beef is $29^{\circ} \mathrm{F}$. if its qualitios are to be preserved. At this temperature, bacterial growth is not entirely stopped and chemical oxidation of the fat continues to take place; consequently there is a time limit of storage in still air of about $\mathbf{3 5}$ days. In these circumstances, it has not been possible for beef to be exported from Australia and New Zealand to England. By storage in carbon dioxide, this time is considerably extended, and some experimential shipments having been successful, the Port Chalmers was designed with gas-tight welded compartments for the carriage of beef, and she has recently completed her maiden voyage. She is a motor-ship, $486 \frac{1}{2} \mathrm{ft}$. long and 11,610 tons dead weight capacity. She has six holds, five of which are insulated, and these can be maintained at various temperatures for chilled beef, frozen mutton, butter, eggs, fruit and other commodities. The refrigerating plant is of the usual type, but in addition there is a large battery of carbon dioxide cylinders from which the gas passes through a British Oxygen Co.'s heater to the chilled beef compartments.

\section{Aluminium in Bridge-work}

AN interesting development in bridge-work is described in the Engineer of July 27, in which is an account of the reconditioning of the Smithfield Street Bridge which crosses the Monongahela River at Pittsburgh. This bridge forms an important link in communication between Pittsburgh proper and the south side, and is used by trolley-cars, motor vehicles and pedestrians. Built partly of wrought iron and partly of steel and erected in 1882, it has at various times been widened and strengthened, but an examination made in 1926 showed that it was being subjected to excessive stresses. The main features of the bridge include two fish belly' trusses of $360-\mathrm{ft}$. span supporting a floor system which included timber decking $11 \mathrm{in.} \mathrm{thick.} \mathrm{At} \mathrm{first} \mathrm{it} \mathrm{was}$ considered a new bridge would have to be built, but financial reasons led to the matter being reconsidered, and it was finally decided to replace the whole of the girders, stringers and decking of the floor by aluminium, thus reducing the dead weight on the trusses. The heat-treated aluminium alloy used has an ultimate strength of about 26 tons, a yield point of about 16 tons and an elongation on 2 in. of 20 per cent, and the total saving in weight is more than 1 ton per lineal foot or $751 \frac{1}{2}$ tons in all. The cost of reconditioning has been 276,436 dollars, whereas the cost of a new bridge would have been about two million dollars. The bridge as it now stands is estimated to have a life of twenty-five years.

\section{Mining and Fuel Research at Sheffield}

THE report on research work earried out in the Departments of Mining and Fuel Technology of the University of Sheffield during 1932-33 (pp. 28. Sheffield : The University, 1933) reveals an extensive range of work bearing on the local industry of coal 
getting and utilisation, such as the ventilating and lighting of mines. Of more general interest, a study of the fireproofing of timber showed that ammonium phosphate gave the best results. In fuel technology, the chemistry of coal and coke takes prominence, while combustion in internal combustion engines is under investigation. The prosecution of applied sciences in a university curriculum has received criticism in recent years, but there can be little doubt that the association of teaching with investigation of such technical problems will be of mutual benefit.

\section{Bibliography of Seismology}

WE have received the last quarterly part for the year 1933 of the valuable "Bibliography of Seismology" edited by Mr. E. A. Hodgson and issued by the Dominion Observatory, Ottawa. This part completes the tenth volume and contains the titles, and in some cases brief abstracts, of one hundred memoirs on seismology, published with fow exceptions during the year 1933. The value of the work is much increased by the addition of two indexes, one of the subjects treated during the past year, the other of the authors, more than one thousand in number, whose works are catalogued in the tenth volume (1929-33).

\section{First Tree Ring Conference}

A CONFERENCE on tree ring studies was held on June 11-12, at the Museum of Northern Arizona at Flagstaff, under the chairmanship of Dr. A. E. Douglass of the University of Arizona. Among the problems discussed was the need for a journal in which to publish the original data on which climatological conclusions and prehistoric dates are based. It was, therefore, decided to publish a quarterly journal to be called the Tree Ring Bulletin, at a subscription price of 1.50 dollars a year. Dr. A. E. Douglass will be editor-in-chief; Dr. Waldo S. Glock, assistant editor ; Dr. Harold S: Colton, managing editor; and Mr. John C. MeGregor, assistant managing editor. While the publication will be of immediate interest to archæologists, it will also deal with problems of climatology and other subjects to which tree ring studies are related. Further information can be obtained from Dr. Harold S. Colton, Museum of Northern Arizona, Flagstaff, Arizona.

\section{Association of Special Libraries and Information Bureaux}

THE eleventh annual Conference of the Association of Special Libraries and Information Bureaux will be held at Somerville College, Oxford, on September 21-24, under the presidency of Sir Richard Gregory. On September 21, Sir Richard will deliver his presidential address entitled "Science in the Public Press", when the chair will be taken by the pastpresident, Sir Charles Sherrington. The morning of September 22 will be devoted to a consideration of "Book Selection for Special and General Libraries", when contributions will be made by Mr. A. F. Ridley, "Book Selection for Special Libraries"; Mr. J. E. Walker, "Methods of Selecting Technical and Refer- ence Books for General Libraries"; and Mr. S. G. Wright, "Book Recommendation Methods for University Libraries". Mr. H. V. Horton will also read a paper on "The Use of the Universal Decimal Classification in Photographic Abstracts". The afternoon will be devoted to a consideration of "Some New Libraries", when Mr. Charles Nowell will describe the "Manchester Central Library", and Mr. H. F. Alexander, the "Radeliffe Science Library, Oxford". In the evening, Mr. L. Urwick will read a paper entitled "The Idea of Planning". The morning of September 23 will be devoted to "Planning in its Relation to Information", when the following papers will be read: Mr. K. M. Lindsay, M.P., "Public Efforts at Planning in Great Britain" ; and Mr. O. W. Roskill, "The Planning of Industry". In the evening, Mr. L. A. de L. Meredith will discuss "Publicity for Great Britain-Problem of the Supply of Information". In addition to members of the Association, the Conference is open to others who are interested. Further information can be obtained from the Secretary, 16, Russell Square, London, W.C.1.

\section{Announcements}

Prof. C. E. Weatherburn, professor of mathematics in the University of Western Australia, has been awarded the Hector Medal and Prize by the Royal Society of New Zealand, for his contributions to the subject of differential geometry.

Messrs. ILford LTD. have recently published a booklet entitled "Photography as an Aid to Scientific Work". It is intended as a guide to the best type of photographic material for any given problem, and as such is to be recommended as a very useful book of reference. It is a common difficulty that workers in laboratories cannot obtain a concise and informative summary of the materials and apparatus now available. In this little book, Messrs. Ilford have succeeded in furnishing such a summary relating to the photographic materials which they manufacture.

Applications are invited for the following appoint. ments, on or before the dates mentioned :-A lecturer in electrical engineering at Swindon Technical College - The Education Officer, Clarence Street, Swindon (Aug. 18). A director of the University Farm, Cambridge-The Secretary, School of Agriculture, Cambridge (Aug. 29). An engineer and ship surveyor for the Mercantile Marine Branch of the Board of TradeThe Senior Staff Officer, Establishment Department (Mercantile Marine Branch), Board of Trade, Great George Street, London, S.W.I (Sept. 12). A borough engineer and surveyor for Croydon-The Town Clerk, Town Hall, Croydon (Sept. 13). A botanist at the Royal Botanic Gardens, Kew - The Secretary, Ministry of Agriculture and Fisheries, 10, Whitehall Place, London, S.W.1 (Sept. 30). A chief chemist in the Public Health Laboratories, Cairo-The Royal Egyptian Legation, Bute House, 75, South Audley Street, London. An assistant information officer to the International Tin Research and Development Council-The Secretary, Manfield House, 378, Strand, London, W.C.2. 